\section{Irish take world's toughest stance on tobacco}

$\mathrm{T}$ he Irish government's increasingly tough attitude towards tobacco is making an impact, since the last remaining major sports event held in the country associated with tobacco-the Irish Masters Snooker tournament-lost its cigarette sponsor last week. Gallaher (Dublin) Ltd, makers of the Benson and Hedges brand that had been part of the tournament for years, said that the government's early introduction of a ban on advertising and tobacco sponsorship has forced the action. It had asked the government for an exemption.

Under European Union (EU) rules, the sports sponsorship ban need not take effect until 2003, but Ireland's Minister of Health, Micheál Martin, has brought forward the deadlines and policies. Martin and the anti-smoking lobby group, ASH Ireland have welcomed the company's departure from the sport. Snooker officials believe that finding another sponsor will be easy because of the large television audience.

The sight of Alex Higgins, cigarette in mouth, was familiar to viewers of snooker. But the former star now has cancer and has joined a group of Irish smokers suing the tobacco industry.
Later this month, Martin intends to introduce stringent new policies that would give Ireland the strictest antitobacco laws in the world. The new legislation would mandate the registration or licensing of all retail outlets selling tobacco. If a shop sells to anyone under 18 years, it will lose its licence to sell tobacco. A pilot survey showed that more than half of shops sell to minors.

Unrestricted access to cigarette vending machines would also be prohibited. Cigarettes in shops will not be allowed on display where children could see them. Martin's aim is to make cigarettes invisible to children and to reduce the general level of smoking from $31 \%$ to $20 \%$ by 2010. Billboard and print advertising has been banned for some time and from now on, all foreign publications on sale in Ireland must also be free of such advertising. The Minister has not yet decided whether to ban the sale of tobacco during certain hours such as when schools finish for the day. $\mathrm{He}$ is also examining the possibility of curbing the use of tobacco logos on clothing and other products that appeal to teenagers.

Karen Birchard

\section{News in brief}

No action on Australian radiologists The Australian federal Director of Public Prosecutions (DPP) has decided not to prosecute 250 radiologists who purchased 33 magnetic-resonance imaging scanners immediately before the 1998 budget announcement (see Lancet 2000; 355: 296-98). The leaked budget had included increased rebates for these procedures. There was evidence that some radiologists backdated contracts for new scanners so as to be eligible for the rebate. The DPP concluded it was not possible to prove beyond reasonable doubt, that the radiologists had intended to defraud the government through excess claims for the rebate.

Belgium invests in mammography At the Second European Breast Cancer Conference on Sept 27, the Belgian Ministries of Social Affairs and Health announced that they will allocate 12 million euros for a systematic breast-cancer screening programme. The goal is to enable all women aged 50-69 years to have free mammography every 2 years. The programme will be introduced with an publicity campaign, aiming to have ultimately $75 \%$ of all women examined. About 2500 women die each year from breast cancer in Belgium.

\title{
Outbreak of Crimean-Congo haemorrhagic fever in Pakistan
}

Qince Sept 12, at least eight people have died as result of an outbreak of suspected Crimean-Congo haemorrhagic fever (CCHF) in Pakistan's western province, Baluchistan. Health officials said that the people who died included two hospital paramedics and five members of the same family living in a region that borders on Afghanistan, which is also a CCHFendemic country. Since June, a similar outbreak in Afghanistan has affected 27 people of whom 16 died.

"The possibility that the disease had been introduced into the province from Afghanistan can't be ruled out", health officials at the National Institute of Health in Islamabad told The Lancet. 3 weeks ago, Iran banned imports of livestock from neighbouring Afghanistan after a CCHF outbreak killed six people in its south-eastern region. According to Iranian health officials, 300000 domestic animals had been smuggled into the country via its eastern border between May and August this year. Since the fever was identified in Iran 2 months ago, more than 400000 animals have been sprayed for ticks.

In the Pakistan outbreak, 22 suspected cases of CCHF had been recorded by Oct 2 . Blood samples taken from cases and contacts have been sent to the National Institute of Virology in South Africa. The Baluchistan health authorities have destroyed tons of meat, milk, and milk-product foods and have issued public-health warnings. In addition, hotel owners have been warned not sell cooked meat or tea with milk. Health officials said they had moved dozens of affected people to the cities of Quetta or
Loralai. "The situation is under control and we have set up isolation ward in the hospital for the affected patients", says Director of General Health for Baluchistan, Naimatullah Gickki.

CCHF, a viral disease transmitted to animals and man by hyalomma ticks, was first observed by Russian scientists in Crimea in 1944; the virus was also isolated from a patient in Zaire in 1956. Since the disease was first identified in Pakistan, this is the eighth reported outbreak of CCHF, raising concerns that the epidemics are becoming more common. But Arif Sarwari (Aga Khan University, Karachi) disagrees: "[the outbreaks] did occur in the past, but were seldom reported; now the reporting has improved".

Khabir Ahmad 